\title{
MYCOPLASMA SYNOVIAE INFECTION IN LAYERS: DIAGNOSIS AND CONTROL MEASURES - A REVIEW
}

\author{
Khaled Kaboudi ${ }^{1}$ and Adem Jbenyeni ${ }^{2}$ \\ ${ }^{1}$ Department of Poultry Farming and Pathology, National Veterinary \\ Medicine School of Sidi Thabet, University of Manouba, Tunisia \\ ${ }^{2}$ UMR INRA-IHAP, Virology Staff, National Veterinary \\ School of Toulouse, Toulouse, France
}

\section{Abstract}

Mycoplasmas are widespread bacteria in domestic and wild birds. Among the important species in laying hen, Mycoplasma gallisepticum and Mycoplasma synoviae, are considered as an emergent pathogen in the last few years worldwide, causing considerable economic losses as a result of falling eggs and the decrease in egg quality. Transmission of M. synoviae occurs horizontally, more rapidly in multi-age sites, and vertically, leading to a decline in hatchability in breeding farms. The interaction between $M$. synoviae and the host's immune system explains the immunosuppression induced by this pathogen. Inside the cell, M. synoviae can escape the immune system by implementing several mechanisms.

Subclinical respiratory infection is often associated to M. synoviae. However, severe disease may be observed in the presence of other factors (respiratory viruses, stressors). The emergence of a new form of clinical manifestation of disease associated to M. synoviae infection has been described since the 2000s. Eggshell apex abnormalities of the produced eggs, associated to high risk of cracks and breakage, is described.

The diagnosis of M. synoviae infection is based on various tests, including serology, culture and biomolecular methods. Control is based on the acquisition of free mycoplasma birds, biosecurity, regular monitoring and vaccination. Management of other risk factors is essential.

Keywords: antibiotic, biosecurity, eggshell apex abnormality, layer hen, Mycoplasma synoviae, PCR; serology, vaccination

\footnotetext{
${ }^{1^{*}}$ Corresponding author: khaled.kaboudi@enmv.uma.tn
} 


\title{
MYCOPLASMA SYNOVIAE INFEKCIJA KOD NOSILJA: DIJAGNOZA I MERE KONTROLE - PREGLED LITERATURE
}

\author{
Khaled Kaboudi ${ }^{1}$ i Adem Jbenyeni ${ }^{2}$ \\ ${ }^{1}$ Katedra za živinarstvo i patologiju, Fakultet Veterinarske \\ medicine, Sidi Thabet, Manuba, Tunis \\ ${ }^{2}$ UMR INRA-IHAP, Odeljenje za virusologiju, Fakultet \\ Veterinarske medicine, Tuluz, Francuska
}

\section{Kratak sadržaj}

Mikoplazme su široko rasprostranjene bakterije kod domaćih i divljih ptica. Tokom poslednjih nekoliko godina, Mycoplasma gallisepticum i Mycoplasma synoviae smatraju se pretećim patogenima širom sveta, koji dovode do značajnih ekonomskih gubitaka zbog smanjene nosivosti i opadanja kvaliteta jaja. Do prenošenja $M$. synoviae dolazi horizontalno, brže na mestima gde se uzgaja živina različite starosti i vertikalno, što dovodi do smanjenja izleganja pilića na priplodnim farmama. Interakcija između $M$. synoviae i imunog sistema domaćina izaziva imunosupresiju. Unutar ćelije, M. synoviae koristi različite mehanizme da zaobiđe imuni sistem domaćina.

Subklinička respiratorna infekcija se često povezuje sa M. synoviae. Međutim, do ozbiljnih kliničkih manifestacija bolesti dolazi u prisustvu drugih faktora (respiratorni virusi, različiti stresogeni). Pojava nove kliničke manifestacije bolesti koja se dovodi u vezu sa infekcijom $M$. synoviae opisuje se od 2000-ih godina. Opisane su nepravilnosti apeksa ljuske jajeta povezanih sa visokim rizikom od pucanja i lomljenja ljuske.

Dijagnoza infekcije $M$. synoviae zasniva se na raznim testovima, uključujući serologiju, kultivisanje i biomolekularne metode. Kontrola se sprovodi redovnim monitoringom, vakcinacijom, biosigurnosnim merama i nabavkom živine koja je slobodna od mikoplazme. Upravljanje drugim rizicima je od suštinske važnosti.

Ključne reči: antibiotik, biosigurnost, apeks jajčane ljuske, koke nosilje, Mycoplasma synoviae, PCR; serologija, vakcinacija

\footnotetext{
${ }^{{ }^{*}}$ Corresponding author: khaled.kaboudi@enmv.uma.tn
} 


\section{INTRODUCTION}

Mycoplasmosis are worldwide infections of domestic and wild birds. Historically, infections were described firstly in turkeys in 1926, then in chicken in 1936 (Nascimento et al., 2005; Kleven 2008). More than 120 species, isolated in mammals, birds, reptiles and fishes, were determined in Mycoplasma genus. Currently, more than 20 species of mycoplasma are considered pathogenic in poultry (Nascimento et al., 2005; Purswell et al., 2011).

Mycoplasma gallisepticum (M. gallisepticum) (chicken and turkey), Mycoplasma synoviae (M. synoviae) (chicken and turkey), Mycoplasma meleagridis (M. meleagridis) (turkey) and Mycoplasma iowae (M. iowae) (turkey) (Stipkovits et Kempf 1996) (in Sprygin et al., 2011) are the most important species.

Mycoplasmosis caused by M. synoviae was firstly described in turkeys in 1926 and in chicken in 1936 (Nascimento et al., 2005, Kleven 2008). M. synoviae is responsible of locomotor disorders, including arthritis, tendinitis and synovitis. However, contrarily to M. gallisepticum, M. synoviae may be incriminated in a subclinical respiratory infection, which can predispose birds to the chronic respiratory disease following interactions with other pathogens (Newcastle disease virus, infectious bronchitis virus, Ornithobacterium rhinotracheale and Escherichia coli).

In last decade, the situation of mycoplasma infections is characterized by the emergence of $M$. synoviae compared to M. gallisepticum and a more pronounced respiratory tropism (aerosacculitis) than the articular tropism, especially in chicken and secondarily in turkey (Khalifa et al., 2013). In laying hens, M. synoviae has been causing serious egg drop problems since the 2000s with alteration of the eggshell quality.

\section{ECONOMIC IMPACT}

Economic impact of Mycoplasma infection in layer hen flocks are well documented regarding to $M$. gallisepticum. Whereas, the economic significance of $M$. synoviae has been a subject of debate for many years. While the increasing occurrence worldwide of arthropathic and amyloidogenic $M$. synoviae strains in poultry as well as strains that induce eggshell apex abnormalities (EAA) and egg production losses (Landman and Feberwee, 2001, 2004; van Beek et al., 2002; Feberwee et al., 2007), has increased attentiveness of the clinical and economic impact of infection with this Mycoplasma. Prevalence of M. synoviae infection in layers in some countries is summarized in Table 1. 
Table 1. Worldwide prevalence of $M$. synoviae in layers

\begin{tabular}{|c|c|c|c|c|c|}
\hline & Country & $\begin{array}{l}\text { Region / pe- } \\
\text { riod of study }\end{array}$ & Analysis & Prevalence & Reference(s) \\
\hline \multirow{6}{*}{ Europe } & France & $\begin{array}{l}\text { Côtes d'Armor, } \\
\text { Brittany / } \\
2002-2003 \\
\end{array}$ & Culture & $68 \%$ & $\begin{array}{l}\text { Dufour-Gesbert } \\
\text { et al. (2006) }\end{array}$ \\
\hline & Germany & - & PCR & $75 \%$ & Kohn et al. (2009) \\
\hline & Netherlands & - & Serology & $73 \%$ & $\begin{array}{l}\text { Landman and Feber- } \\
\text { wee }(2001) ; \text { Feberwee } \\
\text { et al. }(2008,2009) \\
\end{array}$ \\
\hline & Poland & $\begin{array}{l}16 \text { provinces } \\
\text { / } 2010-2016\end{array}$ & PCR & $29 \%$ & Kursa et al. (2019) \\
\hline & Turkey & $\begin{array}{l}\text { Konya re- } \\
\text { gion / } 2010\end{array}$ & $\begin{array}{c}\text { PCR } \\
\text { Serology }\end{array}$ & $\begin{array}{c}25 \% \\
22.5 \% \\
\end{array}$ & $\begin{array}{c}\text { Aras and Sayin } \\
\text { (2014) }\end{array}$ \\
\hline & $U K$ & - & Serology & $78.6 \%$ & Hagan et al. (2004) \\
\hline \multirow{5}{*}{ Africa } & Algeria & Eastern regions & Serology & $26.7 \%$ & Aimeur et al. (2010) \\
\hline & Ghana & $\begin{array}{l}\text { Ga-East district, } \\
\text { Accra region }\end{array}$ & Serology & $75 \%$ & Matilda et al. (2018) \\
\hline & Libya & $\begin{array}{c}\text { Region of Al- } \\
\text { Jabal Al-Gharbi }\end{array}$ & Serology & $28 \% \%^{* \S}$ & $\begin{array}{l}\text { Kammon et } \\
\text { al. (2017) }\end{array}$ \\
\hline & Morocco & Different regions & $\begin{array}{l}\text { Serology } \\
\text { PCR }\end{array}$ & $100 \%{ }^{\star *}$ & Nassik et al. (2014) \\
\hline & Tunisia & $\begin{array}{l}\text { Region of Cap- } \\
\text { Bon ( } 6 \text { districts) }\end{array}$ & $\begin{array}{l}\text { Serology } \\
\text { Culture }\end{array}$ & $\begin{array}{l}28.5 \% \\
9.5 \% \\
\end{array}$ & $\begin{array}{l}\text { Boussetta et } \\
\text { al. (1997) }\end{array}$ \\
\hline \multirow[b]{2}{*}{ Asia } & China & $\begin{array}{l}21 \text { provinces } \\
\text { / } 2010-2015\end{array}$ & Serology & $41.19 \% *$ & Xue et al. (2017) \\
\hline & Pakistan & $\begin{array}{l}\text { Different regions } \\
\text { in Rawalpindi } \\
\text { / 2016-2017 }\end{array}$ & Serology & $42.6 \%$ & Shoaib et al. (2019) \\
\hline Oceania & Australia & Two provinces & Serology & $69 \%$ & Gole et al. (2012) \\
\hline \multirow[t]{2}{*}{ America } & USA & $\begin{array}{l}\text { Southern and } \\
\text { central California }\end{array}$ & Serology & $32-91 \%$ & $\begin{array}{l}\text { Mohammed et } \\
\text { al. (1986) }\end{array}$ \\
\hline & Brazil & $\begin{array}{c}\text { Three States / } \\
\text { 2001-2004 }\end{array}$ & PCR & $22.85 \%$ & Buim et al. (2009) \\
\hline \multicolumn{6}{|c|}{$\begin{array}{l}\text { PCR: Polymerase Chain Reaction; } \\
\text { UK: United Kingdom; USA: United States of America } \\
{ }^{*} \text { different categories of poultry production; }{ }^{* *} \text { broiler breeder flocks; }{ }^{`} M G \text { and MS }\end{array}$} \\
\hline
\end{tabular}


Currently, it is demonstrated that M. synoviae infection causes severe economic losses due to vertical transmission of the germ, resulting in death of embryo, consequently a decrease in hatch rate, significant post-hatch mortality, bacteria diffusion in the hatchery, and quality degradation of day-old chicks. Moreover, M. synoviae may induce transient immunosuppression, an increase in mortality of $1-4 \%$, particularly in broiler chickens, a decrease of $5-10 \%$ in egg production rate, and a decrease of $5-7 \%$ in hatch rate (Mohammed et al., 1987; Stipkovits and Kempf 1996).

Mycoplasmosis due to M. synoviae occurred in layer hens flocks are associated to a decrease in the egg quality (Table 2). Egg-production level can decrease from $86 \%$ to $79 \%$ after three weeks in 54 weeks old layer hens (Jeon et al., 2014). Losses in infected hens are estimated at eight eggs per hen compared to healthy flocks (Mohammed et al., 1987). Additional losses are mentioned in affected flocks due to therapeutic and prophylactic means (Ferguson-Noel and Williams 2015). Similar reports are observed in layer hens flocks in Tunisia. Indeed, a decrease of 5-20\% in eggs production is mentioned, according to the farms registers. The prevalence of $M$. synoviae infections in Tunisian poultry industry remains relatively high. Overall sero-prevalence of 19\% (23 flocks / 63 visited) of all types of production in the Cap-Bon region (north-eastern of Tunisia) is mentioned (Boussetta et al., 1997). The prevalence in layer hens flocks is estimated to $28.5 \%$ ( 6 flocks / 21 visited). Currently, it appears that this prevalence is higher according to field findings, in the absence of official publications.

Table 2. Performance data for negative and positive M. synoviae layer flocks (Hussein, 2017)

\begin{tabular}{ccc}
\hline & M. synoviae free & M. synoviae positive \\
\hline Egg per hen housed & 321 & 300 \\
\hline B-Grade percentage & $2.87 \%$ & $3.76 \%$ \\
\hline FCR & 2.36 & 2.47 \\
\hline Mortality & $5 \%$ & $12.60 \%$ \\
\hline Point of lay pullet price & $£ 3.90$ & $£ 3.90$ \\
\hline Price feed per ton & $£ 210$ & $£ 210$ \\
\hline
\end{tabular}

FCR: Feed conversion ratio

Positive layers do not achieve the optimal weight during the breeding phase allowing them to lay eggs period. Consequently, the production level, the eggs size and the eggshell quality are significantly affected later. 
A new syndrome, called "Eggshell Apex Abnormality" (EAA), has been identified since 2000 in broiler-type breeders and layer hen's flocks. This new form is due to infection by certain strains of M. synoviae that multiply in the hen's genital tract. The presence of such eggs type in layer's flocks in Tunisia has also been reported in many integrations.

The upper part of the eggshell appears translucent, thin and very fragile, so it is easy to break. The demarcation is clear between the normal and the affected parts of the shell (Feberwee et al., 2009; Jeon et al., 2014). Eggshell discoloration was also observed in positive flocks, which further increasing the decommissioning rate of eggs. This rate may rise from $2.6 \%$ to $8.3 \%$ (Jeon et al., 2014). However, other causes, such as infectious bronchitis virus (IBV) and egg drop syndrome'76 virus (EDS'76) may induce more than 25\% of egg quality degradation. Eggs from infected flocks are smaller, with a low commercial value. Because of possible eggshell cracks presence, interior components contamination is reported. The penetration of potential pathogens into affected eggs has been accompanied with the increase of embryo mortality (Hunton 2005).

\section{TRANSMISSION}

One of the ways in which poultry mycoplasma are disseminated is through egg transmission. This mode of transmission eased by the oviduct contamination is mainly observed for $M$. meleagridis and $M$. iowae. Whereas, the contamination of embryonated eggs with M. gallisepticum and M. synoviae is mainly due to the contiguity of the oviduct and contaminated air sacs (Kempf 1997; Dufour-Gesbert et al., 2006). Possible transmission via contaminated semen may also occur during artificial insemination in turkeys.

Transmission of M. gallisepticum and M. synoviae is mainly the consequence of the direct and close contact between animals, where bacteria may penetrate via respiratory and/or conjunctival pathways. Transmission can also occur through indirect contact, due to possible persistence of Mycoplasma for several days in the environment. The involvement of several types of animated (people, wild birds) and inanimate vectors (vehicles, food, water...) has been also established (Figure 1). 


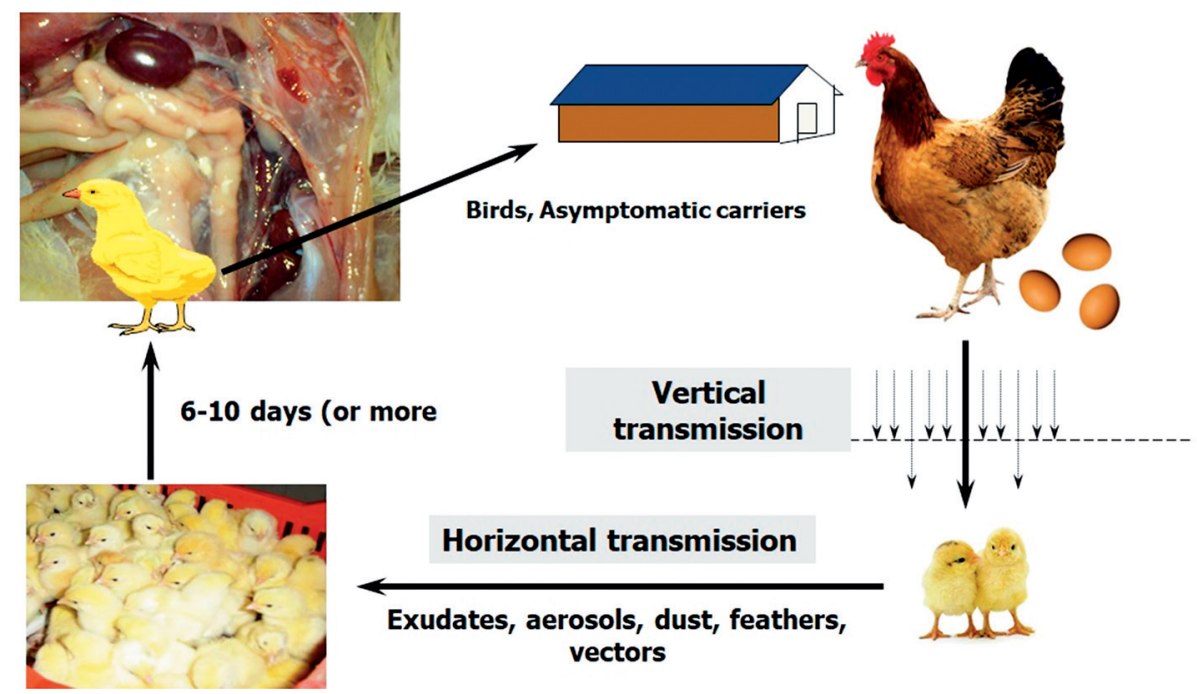

Figure 1. Transmission ways of Mycoplasma synoviae in poultry

Once infected, birds may be able to carry asymptomatically the bacteria even throughout the production period. Furthermore, because of the extension of poultry farms and the concentration of large integrations with multiage flocks in restricted geographical areas, maintaining the free-status of flocks becomes very difficult.

\section{PATHOGENICITY AND INTERACTION WITH OTHER PATHOGENS}

M. synoviae is involved in several types of disorders: respiratory, articular and genital. In general, this bacteria causes subclinical respiratory infection (Kleven 2008). However, it may evolve progressively and will induce air sacculitis lesions, particularly when mycoplasma infection is exacerbated by other pathogens such as Newcastle disease virus (NDV), IBV and avian influenza virus (AIV), or when birds are infected with highly virulent $M$. synoviae strains (Lockaby et al., 1999; Santos et al., 2014; Umar et al., 2017). Experimental infection of breeder hens with virulent $M$. synoviae strain can induce EAA eggs production from the sixth day after a single intra-tracheal inoculation if preceded by an infection with IBV. In addition, the mean daily egg production per hen was significantly reduced by the M. synoviae EAA strain in SPF egg layers (Feberwee and Landman, 2010). 
It is currently well established that mycoplasmas cause immunosuppression in infected birds. Indeed, these bacteria cause excessive release of pro-inflammatory cytokines, inhibit phagocytosis, and affect the B-cells and T-cells functions (Stipkovits et al., 2012).

Several escape mechanisms to the host immune response were described in mycoplasmas to explain the existence of chronic infections and some therapeutic failures. These include intracellular location, molecular mimicry (recognition of mycoplasmas surface epitopes as well as the self by the immune system) and antigenic variability (Bencina et al., 1994; Garcia et al., 1994; Kleven 1998; Nascimento et al., 2005).

In systemic infection, $M$. synoviae may cause articular disorders. The first cases of infectious synovitis have been described on broiler chickens since the 1950s and 1960s. While in layer hens, M. synoviae was found to be involved in lesions of ovaritis, salpingitis and peritonitis. Co-infection of layers with virulent strains of $M$. synoviae and E. coli increase significantly the mortality. Virulent MS strains can act as a complicating factor in the layer $E$. coli peritonitis syndrome (Raviv et al., 2007).

Moreover, M. synoviae vaccines may predispose poultry to severe viral and bacterial infections. Immunosuppressed layer hens have been shown high levels of viral particles in tissues caused by AIV, subtype H9N2 (Kwon et al., 2008; Umar et al., 2017). Similarly, immunosuppression can increase the susceptibility of hens to bacteria and viruses infections (Subler et al., 2006). More severe clinical signs and lesions following inoculation of chickens by M. gallisepticum and H3N8, compared to animals infected with M. gallisepticum or H3N8 alone are illustrated (Stipkovits et al., 2012).

\section{DIAGNOSIS}

Field diagnosis of $M$. synoviae infection is difficult because of the nonspecific clinical signs, lesions and the numerous similar diseases. That is why, laboratory investigations are very important to confirm clinical suspicion. Rapid detection of infection is demanded to prevent spread and reduce economic losses. Several direct and indirect diagnostic methods are available (Table 3). 
Table 3. Comparative elements of the main diagnostic techniques of $M$. synoviae infections

\begin{tabular}{|c|c|c|c|c|c|c|}
\hline & Method & $\begin{array}{c}\text { Application } \\
\text { domain }\end{array}$ & $\begin{array}{l}\text { Detected } \\
\text { element }\end{array}$ & SP / SE & Advantages & Disadvantages \\
\hline \multirow{2}{*}{$\begin{array}{l}\text { Direct } \\
\text { diag- } \\
\text { nosis }\end{array}$} & $\begin{array}{l}\text { Bacteri- } \\
\text { ology }\end{array}$ & Research & Colonies & $\begin{array}{l}\mathrm{SP}+++ \\
\mathrm{SE}++\end{array}$ & $\begin{array}{l}\text {-Strain isolation } \\
\text {-Depth study of strains } \\
\text {-Antimicrobial sus- } \\
\text { ceptibility studies }\end{array}$ & $\begin{array}{l}\text {-Low time limit: } 2-3 \text { weeks } \\
\text {-Cost (identification method) } \\
\text {-Culture media very complex } \\
\text {-Sometimes, growth inhibi- } \\
\text { tion in favor to other bacteria }\end{array}$ \\
\hline & PCR & $\begin{array}{l}\text {-Diagnostic } \\
\text {-Research }\end{array}$ & DNA & $\begin{array}{l}\mathrm{SP}+++ \\
\mathrm{SE}+++\end{array}$ & $\begin{array}{l}\text {-Affordable cost } \\
\text {-Transport of sam- } \\
\text { ples less restrictive } \\
\text {-Rapid response }\end{array}$ & Detection of dead bacteria \\
\hline \multirow[t]{2}{*}{$\begin{array}{c}\text { Indirect } \\
\text { diag- } \\
\text { nosis }\end{array}$} & RPA & $\begin{array}{l}\text { Flock's } \\
\text { Surveillance }\end{array}$ & $\operatorname{IgM}(\operatorname{IgG})$ & $\begin{array}{l}\mathrm{SP}+/- \\
\mathrm{SE}++\end{array}$ & $\begin{array}{l}\text {-Early detection } \\
\text { (7-10 days) } \\
\text {-Low cost } \\
\text {-Very rapid } \\
\text {-Applicability in farms }\end{array}$ & $\begin{array}{l}\text {-Test repetition needed } \\
\text {-Risk of false-positives }\end{array}$ \\
\hline & ELISA & $\begin{array}{l}\text {-Surveillance } \\
\text {-Diagnosis }\end{array}$ & $\operatorname{IgG}$ & $\begin{array}{l}\mathrm{SP}+ \\
\mathrm{SE}++\end{array}$ & $\begin{array}{l}\text {-Facile use } \\
\text {-Automatable } \\
\text {-Rapid response }\end{array}$ & $\begin{array}{l}\text {-Cost } \\
\text {-Availability }\end{array}$ \\
\hline
\end{tabular}

DN : Deoxyribonucleic Acid; RPA: Rapid Plate Agglutination;

ELISA : Enzyme Linked ImmunoSorbent Assay;

Ig: Immunoglobulin; PCR : Polymerase Chain Reaction; SE : Sensitivity; SP : Specificity

The mycoplasma infection diagnosis has been based on three techniques for several decades: bacteria isolation and identification, detection of specific antibodies and detection of bacterial DNA (deoxyribonucleic acid) by PCR (Polymerase Chain Reaction) (Dufour-Zavala et al., 2008; OIE 2008; Qasem et al., 2015).

Serological investigations are widely used for preliminary diagnosis and screening. The most commonly used tests are rapid plate agglutination (RPA) and the immuno-enzymatic technique, ELISA (enzyme linked immunosorbent assay). The hemagglutination inhibition (HI) test is generally performed to confirm positive results (Gole et al., 2012; Khalifa et al., 2013; Michiels et al., 2015). Furthermore, positive serology must be verified by bacteria isolation and identification or by PCR, because of false-positive results and cross-reaction problems, which can be expected in about any serologic test (Feberwee et al., 2005; Heleili et al., 2012). Therefore, it is not advisable to rely completely on one diagnosis test only. 
The ELISA test is used for the detection of specific antibodies against $M$. gallisepticum and M. synoviae in serum and egg yolk. This allows the evaluation of population immunity and transferred passive immunity (Hagan et al., 2004). Association between ELISA serological status for M. synoviae and egg quality parameters, such as translucency, shell breaking strength, percentage of shell reflectivity and shell deformation, has been established (Gole et al., 2012). Similarly, RPA can be applied to egg yolks, where the results are considered positive, negative and uncertain for antibody titles greater than or equal to 1:10, 1:5 and less than 1:5, respectively (Heleili et al., 2012; Nadeem et al., 2014).

The Mycoplasma culture is laborious, slow and expensive laboratory method, requiring sterile conditions. Problems with culture include the proliferation of faster-growing Mycoplasma species and the growth of other saprophytic organisms, such as M. gallinarum and M. gallinaceum. The detection of first colonies may take up to four weeks and, even in this case, negative culture or compromised result by mixed infections can be reported (Ferguson-Noel and Williams 2015).

Due to the disadvantages of conventional diagnosis techniques, the use of molecular methods is very helpful. The PCR, a rapid test, is characterized by high sensitivity and specificity. This technique allows the mycoplasma detection in clinical samples even from asymptomatic infected and/or treated birds (Evens et al., 2005; Peebles et al., 2014; Kursa et al., 2019). M. synoviae may be detected in different types of clinical samples issued from layer hens flock producing eggs with abnormal apex (Catania et al., 2010). Different variants of PCR are used for the detection of the four common mycoplasma species (M. gallisepticum, $M$. synoviae, $M$. meleagridis and $M$. iowae) in the same sample, including real-time PCR (Bagheri et al., 2011; Fraga et al., 2013). Furthermore, PCR has the advantage of detecting co-infections with numerous field and vaccine strains of respiratory pathogens (M. synoviae, M. gallisepticum, IBV, avian metapneumovirus) (Buim et al., 2009; Hutton et al., 2017; Ball et al., 2018; Fujisawa et al., 2019). The use of random amplification of polymorphic DNA to establish the DNA profile may be used for epidemiological investigations and/or for rapid identification of strains (Charlton et al., 1999; Aras and Sayin 2014).

\section{CONTROL}

Control of Mycoplasma infections is based in general, on three complementary approaches: biosecurity, antibiotics preventive treatments and vaccination. Due to the vertical transmission and the absence of walls of the germs, making them more fragile in the outside environment, control of M. synoviae 
infections is theoretically easy. Voluntary programs of M. synoviae eradication are implemented in some countries, such as the United States and the United Kingdom. Similarly, because of the increase in M. synoviae infections prevalence in poultry farms, Germany started a mandated eradication control program in January 2013 in all types of production, excepted of broiler flocks (Feberwee et al., 2017).

The destruction of grandparents and M. gallisepticum confirmed positive breeders is a measure implemented in some countries, including the Netherlands. However, the control of M. synoviae is currently limited to the application of biosecurity programs, the screening of breeder's flocks and voluntary slaughter of infected grandparents in some countries. Vaccination against $M$. synoviae can be performed as an additional measure to reduce infection pressure in multi-age flocks of commercial layer hens.

The first defence barrier is the application of the all-in-all-out band, associated to good biosecurity and monitoring program. However, in a multi-age system, layers flocks are usually infected by M. gallisepticum and M. synoviae in most regions of the world, which presents a potential risk of infection transmission to broiler flocks.

The first step in controlling Mycoplasma infections is the acquisition of fertile eggs and Mycoplasma-free birds. Treatment of hatching eggs by heating ( $46^{\circ} \mathrm{C}$ for $12-14$ hours), or more effectively, by injecting antibiotics, either by an in-ovo injector or by dipping into an antibiotic solution, are different methods used for the eradication of the infection in grandparents (Nascimento and Nascimento 1994; Stipkovits and Kempf 1996).

National certification programs have contributed to the control of Mycoplasma infections in many countries, such as the United States (USA 1997), Brazil (Villa, 1998) (in Nascimento et al., 2005) and France (Official Hygienic and Sanitary Control) (Stipkovits and Kempf 1996). Monitoring is carried out by serological methods such as SPA, ELISA and/or HI. In Tunisia, the control of M. gallisepticum, M. synoviae and M. meleagridis is also based on an OHSC using the SPA technique. Mycoplasma detection is frequently confirmed by PCR (Nascimento et al., 1994; Nascimento et al., 1998).

Mycoplasma monitoring is targeting breeding and commercial laying farms. Analyses are performed on a number of animals, chosen randomly, that vary according to the incidence of infection. Two samples are taken from breeding animals in Tunisia, between 10-12 weeks and between 20-24 weeks, on $2.5 \%$ of the total effective for M. gallisepticum and 5\% for M. synoviae.

Antibiotic treatments can be administered in contaminated environments as a preventive measure, especially during stress period, or as part of a curative 
treatment. The administration of antibiotic as preventive tool is very common in several countries, including Tunisia. Several antibiotic molecules are used; these include macrolides (tylosin, tylvalosin, tiamulin, tilmycosin), tetracyclines (oxytetcracycline, doxicycline) and aminosides (spectinomycin) (Bébéar and Kempf 2005); Kreizinger et al., 2017). Tetracyclines, due to their relatively low cost, are primary antibiotics in the treatment of avian mycoplasmosis.

The implemented programs vary widely across countries, regions and farms. However, the emergence of antimicrobial resistance in M. synoviae limits the use of this control approach. Therefore, the study of the sensitivity profiles of field-isolated strains to antibiotic molecules is a fundamental step towards improving the effectiveness of medical protocols. However, although the treatments reduce significantly clinical signs, mycoplasma may be further isolated after cessation of antibiotic administration, when animals are infected by resistant strains (Reinhardt et al., 2005; Carrou et al., 2006).

Vaccination against M. synoviae is performed especially in breeders and layers to prevent clinical signs and bacteria spread. Currently there are two commercialized live attenuated vaccines available against $M$. synoviae: the temperature sensitive MS-H vaccine strain and the NAD independent MS1 vaccine strain (Kreizinger et al., 2018). Interaction of these vaccines with other respiratory pathogens is documented. Indeed, M. synoviae vaccine strains can modify AIV replication and immune responses. Furthermore, live vaccines can act as a complicating factor during respiratory co-infection in layers, which may subsequently lead to vaccination strategies advance against poultry respiratory pathogens, in general (Umar et al., 2017).

The immunization of animals against $M$. synoviae must consider the following properties:

- It is shown that vaccination minimizes vertical and horizontal transmission of M. synoviae. Active immunization can prevent and/or reduce clinical signs but does not prevent colonization of internal organs by wild strains (Jones et al., 2006; Noormohammadi et al., 2007; Feberwee et al., 2009).

- Immunization may be accompanied by seroconversion, which must be assessed through a monitoring system that does not interfere with other official control programs (Markham et al., 1998; Feberwee et al., 2009). Thus, differentiation of vaccine strains from field isolates is essential during vaccination and eradication programs. It is essential to establish a Differentiating Infected from Vaccinated Animals (DIVA) system based on multi-technique approach (Dijkman et al., 2016; Moronato et al., 2018). 
Differentiation between vaccine and wild strain was investigated using nested PCR. This technique allows the presence of an adenine in a nucleotide at position 468 of the oppF-1 gene of the vaccine strain of M. synoviae-H. Indeed, the above-mentioned authors show the exclusivity of this mutation in the vaccine strain, compared to wild M. synoviae strains isolated in Australia (Zhu et al., 2017). Recently, differentiation between M. synoviae vaccine and field strains was performed with indirect ELISA based on OppF-C gene (Kordafshari et al., 2019). Furthermore, a melt-curve and agarose gel-based mismatch amplification mutation assays (MAMA) was recently provided to discriminate the MS1 vaccine strain from the MS-H vaccine strain and wildtype M. synoviae isolates (Kreizinger et al., 2018). However, these assays are limited by the available facilities and the cost.

\section{CONCLUSION}

Despite the lack of official data on the incidence of $M$. synoviae and its economic impact in layers, it appears that this mycoplasma is gaining increasing interest around the world. Although M. synoviae cause usually a subclinical respiratory infection, it is responsible for several articular and genital disorders. Moreover, the interaction between field and vaccine strains of M. synoviae and other viral and bacterial infections increase usually the severity of clinical signs and lesions, and consequently the economic losses. In layer hens, M. synoviae infection has been accompanied since the beginning of 2000 s by a new form, characterized by EAA eggs with a very fragile apex shell. Significant withdrawing rates for affected eggs, justifies the importance of implementing appropriate control measures. In this sense, control of M. synoviae infection in layers should be based on an integrated approach involving biosecurity, vaccination, and regular surveillance. These should be well performed to limit the problem of mycoplasmas persistence in infected flocks, especially in multi-age integrations, and minimize economic losses.

\section{Authors' contributions}

Authors contributed equally to this manuscript.

\section{Competing interest}

Authors declared no conflict of interests regarding the present paper. 


\section{REFERENCES}

1. Aimeur R., Bouaziz O., Kabouia R., Bererhi E.H. 2010. Prévalence de Mycoplasma gallisepticum et de Mycoplasma synoviae dans les élevages avicoles de l'Est Algérien. Revue Médecine Vétérinaire, 161(3), 141-145.

2. Aras Z. and Sayin Z. 2014. Molecular Epidemiology of Mycoplasma synoviae Infection in Commercial Layers. Kafkas Univ Vet Fak Derg, 20 (1), 83-87. doi: 10.9775/kvfd.2013.9488.

3. Bagheri H., Doosti A., Arshi A. 2011. Detection of Mycoplasma gallisepticum in Chaharmahal Va Bakhtiari Province poultry using PCR. Global Veterinaria, 7, 54-59.

4. Ball C., Forrester A., Ganapathy K. 2018. Co-circulation of genetically diverse population of vaccine related and unrelated respiratory mycoplasmas and viruses in UK poultry flocks with health or production problems. Veterinary Microbiology, 225, 132-138. doi.org/10.1016/j.vetmic.2018.09.009

5. Bébéar C.M. and Kempf I. 2005. Antimicrobial therapy and antimicrobial resistance. In Mycoplasmas. Molecular biology, pathogenicity and strategy for control. Eds. A. Blanchard and G.F. Browning, Horizon Bioscience, Norfolk pp.535-568.

6. Bencina D., Kleven S.H., Elfaki M.G., Snoj A., Dovc P., Dorrer D., Russ I. 1994. Variable expression of epitopes on the surface of Mycoplasma gallisepticum demonstrated with monoclonal antibodies. Avian Pathology, 23, 19-36.

7. Boussetta M., Chaouachi N., Mlik B. 1997. Etude sérologique et bactériologique des mycoplasmoses aviaires dans la région du Cap Bon en Tunisie. Revue Élev Méd vét Pays trop, 50, 93-96.

8. Buim M.R., Mettifogo E., Timenetsky J., Kleven S., Piantino Ferreira A.J. 2009. Epidemiological survey on Mycoplasma gallisepticum and M. synoviae by multiplex PCR in commercial poultry. Pesq Vet Bras, 29(7), 552-556.

9. Catania S., Bilato D., Gobbo F., Granato A., Terregino C., Iob L., Nicholas R.A. 2010. Treatment of eggshell abnormalities and reduced egg production caused by Mycoplasma synoviae infection. Avian Dis, 54, 961-964.

10. Dijkman R., Feberwee A., Landman W.J.M. 2017. Development, validation and field evaluation of a quantitative real-time PCR able to differentiate between field Mycoplasma synoviae and the MS-H-live vaccine strain. Avian Pathology, 46, 403-415. doi: 10.1080/03079457.2017.1296105

11. Dufour-Gesbert F., Dheilly A., Marois C., Kempf I. 2006. Epidemiological study on Mycoplasma synoviae infection in layers. Veterinary Microbiology, 114 (1-2), 148-154. doi.org/10.1016/j.vetmic.2005.10.040

12. Dufour-Zavala L., Swayne D.E., Glisson J.R., Pearson J.E., Reed W.M., Jackwood M.W., Woolcock P.R. 2008. A laboratory manual for the isolati- 
on, identification and characterization of avian pathogens. 5th eds. American Association of Avian Pathologists, Athens, GA. pp. 59-64.

13. Evans J.D., Leigh S.A., Branton S.L., Collier S.D., Pharr G.T., Bearson S.M.D. 2005. Mycoplasma gallisepticum: Current and developing means to control the Avian pathogen. Journal of Applied Poultry Research, 14, 757-763.

14. Feberwee A. and Landman W.J., 2010. Induction of eggshell apex abnormalities in broiler breeder hens. Avian Pathology, 39(2), 133-137. doi: 10.1080/03079451003657637.

15. Feberwee A., de Vries T., Landman W.J.M. 2008. Seroprevalence of Mycoplasma synoviae in Dutch commercial poultry farms. Avian Pathology, 37 (06), 629-633.

16. Feberwee A., de Wit J.J., Landman W.J.M. 2007. Mycoplasma synoviaeassociated eggshell apex abnormalities. In Proceedings, 15th World Veterinary Poultry Congress, Beijing, China p. 234.

17. Feberwee A., de Wit J.J., Landman W.J.M. 2009. Induction of eggshell apex abnormalities by Mycoplasma synoviae: field and experimental studies. Avian Pathology, 38, 77-85.

18. Feberwee A., Dijkman R., Klinkenberg D., Landman W.J.M. 2017. Quantification of the horizontal transmission of Mycoplasma synoviae in nonvaccinated and M. Synoviae-H vaccinated layers. Avian Pathology, 46, 346-358, doi: 10.1080/03079457.2017.1282602.

19. Feberwee A., Mekkes D.R., de Wit J.J., Hartman E.G., Pijpers A. 2005. Comparison of culture, PCR, and different serologic tests for detection of Mycoplasma gallisepticum and Mycoplasma synoviae infections. Avian Diseases, 49(2), 260-268.

20. Ferguson-Noel N.M. and Williams S.M. 2015. The efficacy of Mycoplasma gallisepticum K-strain live vaccine in broiler and layer chickens. Avian Pathology, 44, 75-80.

21. Fraga A.P., De Vargas T., Ikuta N., Fonseca A.S., Celmer Á.J., Marques E.K., Lunge V.R. 2013. A Multiplex real-time PCR for detection of Mycoplasma gallisepticum and Mycoplasma synoviae in clinical samples from Brazilian commercial poultry flocks. Brazilian Journal of Microbiology, 44, 505-510.

22. Fujisawa S., Murata S., Takehara M., Katakura K., Hmoon M.M., Win S.Y., Ohashi K. 2019. Molecular detection and genetic characterization of Mycoplasma gallisepticum, Mycoplama synoviae, and infectious bronchitis virus in poultry in Myanmar. BMC Veterinary Research, 15, 261. doi. org/10.1186/s12917-019-2018-2.

23. Garcia M., Elfaki M.G., Kleven S.H. 1994. Analysis of the variability in expression of Mycoplasma gallisepticum surface antigens. Veterinary Microbiology, 42, 147-158. 
24. Gole V.C., Chousalkar K.K., Roberts J.R. 2012. Prevalence of antibodies to Mycoplasma synoviae in laying hens and possible effects on eggshell quality. Preventive Veterinary Medicine, 106(1), 75-78. doi: 10.1016/j.prevetmed.2012.02.018.

25. Hagan J.C., Ashton N.J., Bradbury J.M., Morgan K.L. 2004. Evaluation of an egg yolk enzyme-linked immunosorbent assay antibody test and its use to assess the prevalence of Mycoplasma synoviae in UK laying hens. Avian Pathology, 33(1), 93-97.

26. Heleili N., Ayachi A., Mamache M., Chelihi A. 2012. Seroprevalence of Mycoplasma synoviae and Mycoplasma gallisepticum at Batna commercial poultry farms in Algeria. Veterinary World, 5, 709-712.

27. Hunton P. 2005. Research on eggshell structure and quality: an historical overview. Brazilian Journal Poultry Science, 7(2), 67-71.

28. Hussein K. 2017. True cost of Mycoplasma synoviae in commercial layers. Poultry World, May 22 (https://www.poultryworld.net/Health/Articles/2017/5/True-cost-of-Mycoplasma-synoviae-in-commercial-layers135827E/)

29. Hutton S., Bettridge J., Christley R., Habte T., Ganapathy K. 2017. Detection of infectious bronchitis virus 793B, avian metapneumovirus, Mycoplasma gallisepticum and Mycoplasma synoviae in poultry in Ethiopia. Trop Anim Health Prod, 49, 317-322. DOI 10.1007/s11250-016-1195-2.

30. Jeon E.O., Kim J.N., Lee H.R., Koo B.S., Min K.C., Han M.S., Lee S.B., Bae Y.J., Mo J.S., Cho S.H., Lee C.H., Mo I.P. 2014. Eggshell apex abnormalities associated with Mycoplasma synoviae infection in layers. Journal Veterinary Science, 15(4), 579-582.

31. Jones J.F., Whithear K.G., Scott P.C., Noormohammadi A.H. 2006. Duration of immunity with Mycoplasma synoviae: comparison of the live attenuated vaccine MS-H (Vaxsafe MS) with its wild-type parent strain, 86079/7NS. Avian Diseases, 50, 228-231.

32. Kammon A., Mulatti P., Lorenzetto M., Ferre N., Sharif M., Eldaghayes I., Dayhum A. 2017. Biosecurity and geospatial analysis of mycoplasma infections in poultry farms at Al-Jabal Al-Gharbi region of Libya. Open Veterinary Journal, 7(2), 81-85. DOI: 10.4314/ovj.v7i2.1

33. Kempf I. 1997. Les mycoplasmoses aviaires. Le Point Vétérinaire, 28(182), 41-48.

34. Khalifa K.A., Abdelrahim E.S., Badwi M., Mohamed A.M. 2013; Isolation and molecular characterisation of Mycoplasma gallisepticum and Mycoplasma synoviae in chickens in Sudan. Journal of Veterinary Medicine, Article ID 208026, doi:10.1155/2013/208026. 
35. Kleven S.H. 1998. Mycoplasmas in the etiology of multifactorial respiratory disease. Poultry science, 77, 1146-1149.

36. Kleven S.H. 2008. Control of avian mycoplasma infections in commercial poultry. Avian Diseases, 52, 367-374.

37. Köhn S., Spergser J., Ahlers C., Voss M., Bartels T., Rosengarten R., Krautwald-Junghanns M.E. 2009. Prevalence of Mycoplasmas in commercial layer flocks during laying period. Berl Munch Tierarztl Wochenschr, 122(5-6), 186-192.

38. Kordafshari S., Marenda M.S., O'Rourke D., Shil P., Noormohammadi A.H. 2019. Mutation of oppF gene in the Mycoplasma synoviae MS-H vaccine strain and its implication for differential serological responses to vaccination versus field challenge. Veterinary Microbiology, 231, 48-55. doi: 10.1016/j.vetmic.2019.02.029.

39. Kreizinger Z., Grózner D., Sulyok K.M., Nilsson K., Hrivnák V., Benčina D., Gyuranecz M. 2017. Antibiotic susceptibility profiles of Mycoplasma synoviae strains originating from Central and Eastern Europe. BMC Veterinary Research, 13, 342. doi 10.1186/s12917-017-1266-2.

40. Kreizinger Z., Sulyok K.M., Grózner D., Bekő K., Dán Á., Szabó Z., Gyuranecz M. 2018. Development of mismatch amplification mutation assays for the differentiation of MS1 vaccine strain from wild-type Mycoplasma synoviae and MS-H vaccine strains. PLoS One, 12(4), e0175969. doi: 10.1371/journal.pone.0175969.

41. Kursa O., Tomczyk G., Sawicka A. 2019. Prevalence and phylogenetic analysis of Mycoplasma Synoviae strains isolated from Polish chicken layer flocks. Journal Veterinary Research, 63(1), 41-49. doi: 10.2478/jvetres-2019-0010

42. Kwon J-S., Lee H-J., Lee D-H., Lee Y-J., Mo I-P., Nahm S-S., Kim M-J., Lee J-B., Park S-Y., Choi I-S., Song C-S. 2008. Immune responses and pathogenesis in immunocompromised chickens in response to infection with the H9N2 low pathogenic avian influenza virus. Virus Research, 133, 187-194.

43. Landman W.J.M. and Feberwee A. 2001. Field studies on the association between amyloid arthropathy and Mycoplasma synoviae infection, and experimental reproduction of the condition in brown layers. Avian Pathology, 30, 629-639.

44. Landman W.J.M. and Feberwee A. 2004. Aerosol-induced Mycoplasma synoviae arthritis: the synergistic effect of infectious bronchitis virus infection. Avian Pathology, 33, 591-598.

45. Le Carrou J., Reinhardt A.K., Kempf I., Gautier-Bouchardon A.V. 2006. Persistence of Mycoplasma synoviae in hens after two enrofloxacin treatments and detection of mutations in the par C gene. Vet Res, 37, 1-24. 
46. Lockaby S.B., Hoerr F.J., Lauerman L.H., Smith B.F., Samoylov A.M., Toivio-Kinnucan M.A., Kleven S.H. 1999. Factors associated with virulence of Mycoplasma synoviae. Avian Diseases, 43, 251-261.

47. Markham P.F., Glew M.D., Browning G.F., Whithear K.G., Walker I.D. 1998. Expression of two members of the pMGA gene family of Mycoplasma gallisepticum oscillates and is influenced by -specific antibodies. Infect Immun, 66, 2845-2853.

48. Matilda A.A., Linda A.A., Cornelius A., Korley K.N., Paa T.A. 2018. Activity of Mycoplasma synoviae in Commercial Chickens in Ghana: Serological Evidence. Advances in Life Science and Technology, 62.

49. Michiels T., Welby S., Vanrobaeys M., Quinet C., Rouffaer L., Lens L., Martel A., Butaye P. 2015. Prevalence of Mycoplasma gallisepticum and Mycoplasma synoviae in commercial poultry, racing pigeons and wild birds in Belgium. Avian Pathology, 45, 244-252. doi.org/10.1080/03079457.2016.1145354.

50. Mohammed H.O., Carpenter T.E., Yamamoto R. 1987. Economic impact of Mycoplasma gallisepticum and M. synoviae in commercial layer flocks. Avian Diseases, 3, 477-482.

51. Mohammed H.O., Carpenter T.E., Yamamoto R., McMartin D.A. 1986. Prevalence of Mycoplasma gallisepticum and M. synoviae in commercial layers in southern and central California. Avian Diseases, 30, 519-526.

52. Moronato M.L., Cecchinato M., Facchetti G., Mainenti M., Gobbo F., Catania S. 2018. Application of different laboratory techniques to monitor the behaviour of a Mycoplasma synoviae vaccine (MS-H) in broiler breeders. BMC Veterinary Research, 14(1), 357. doi: 10.1186/s12917-018-1669-8.

53. Nadeem M., Yousaf A., Iqbal Z., Awais M.M., Pervez B.A. 2014. Prevalence, diagnosis and treatment of mycoplasmosis in game birds. World's Poultry Science Journal, 70, 69-80.

54. Nascimento E.R. and Nascimento M.G.F. 1994. Eradication of Mycoplasma gallisepticum and M. synoviae from a chicken flock in Brasil In: The 3th Western Poultry Disease Conference; Sacramento, Califórnia, USA. p.58.

55. Nascimento E.R., Nascimento M.G.F., Danelli M.G.M., Machado S.L., Lignon G.B., Polo P.A. 1998. Comparison of PCR kits for the detection of Mycoplasma gallisepticum and M. synoviae (MS) in MS infected and uninfected chickens. In: Proceedings, 47th Western Poultry sease Conference; Sacramento, Califórnia, USA. p84-86.

56. Nascimento E.R., Pereira V.L.A., Nascimento M.G.F., Barreto M.L. 2005. Avian Mycoplasmosis update. Brazilian Journal of Poultry Science, 7, 01-09.

57. Nassik S., Aboukhalid R., Azzam F., Rahmatallah N., Lahlou-Amine I., Fassi-Fihri O., El Houadfi M. 2014. Detection of Mycoplasma synoviae In- 
fection in Broiler Breeder Farms of Morocco Using Serological Assays and Real Time PCR. Journal of Life Sciences, 8, 815-821. doi: 10.17265/19347391/2014.10.004

58. Noormohammadi A.H., Hemmatzadeh F., Whithear K.G. 2007. Safety and efficacy of the Mycoplasma synoviae MS-H Vaccine in Turkeys. Avian Diseases, 51, 550-554.

59. Organisation Mondiale de la Santé Animale (OIE) 2008. Avian mycoplasmosis (Mycoplasma gallisepticum, Mycoplasma synoviae). In: Manual of diagnostic tests and vaccines for terrestrial animals pp. 525-541.

60. Peebles E.D., Jacob R., Branton S.L., Gerard P.D. 2014. Effects of Mycoplasma gallisepticum vaccination on serum $\alpha 1$-acid glycoprotein concentrations in commercial layer chickens. Poultry Science, 93, 1396-402.

61. Purswell J.L., Evans J.D., Branton S.L. 2011. Serologic response of roosters to gradient dosage levels of a commercially available live F strain-derived Mycoplasma gallisepticum vaccine over time. Avian Diseases, 55, 490-494.

62. Qasem J.A., Al-Mouqati S.A., Al-Ali E.M., Ben-Haji A. 2015. Application of molecular and serological methods for rapid detection of Mycoplasma gallisepticum Infection (Avian mycoplasmosis). Pakistan Journal of Biological Sciences, 18, 81-87.

63. Raviv Z., Ferguson-Noel N., Laibinis V., Wooten R., Kleven S.H. 2007. Role of Mycoplasma synoviae in Commercial Layer Escherichia coli Peritonitis Syndrome. Avian Diseases, 51(3), 685-690.

64. Reinhardt A.K., Gautier-Bouchardon A.V., Gicquel-Bruneau M., Kobisch M., Kempf I. 2005. Persistence of Mycoplasma gallisepticum in chickens after treatment with enrofloxacin without development of resistance. Vet Microbiol, 106, 129-137.

65. Santos F.C., Brandão M.D.M., Silva C.C., Machado L.S., Soares M.V., Barreto M.L., Nascimento E.R., Pereira V.L.A. 2014. Eggshell apex abnormalities in a free-range hen farm with Mycoplasma synoviae and infectious bronchitis virus in Rio de Janeiro state, Brazil. Brazilian Journal of Poultry Science, 16: 101-104.

66. Shoaib M., Riaz A., ul Hassan M., Yousaf A., Ur Rehman S., Zafar M.A., Kamran M., Amir R.M., Malik A.M. 2019. Sero-Prevalence and Associated Risk Factors of Mycoplasma Gallisepticum, Mycoplasma Synoviae and Salmonella Pullorum / Gallinarium in poultry. Pakistan Veterinary Journal, in press. doi: $10.29261 /$ pakvetj/2019.097

67. Sprygin A.V., Elatkin N.P., Kolotilov A.N., Volkov M.S., Sorokina M.I., Borisova A.V., Andreychuk D.B., Mudrak N.S., Irza V.N., Borisov A.V., Drygin V.V. 2011. Biological characterisation of Russian Mycoplasma gallisepticum field isolates. Avian Pathology, 40, 213-219. 
68. Stipkovits L. and Kempf I. 1996. Mycoplasmoses in poultry. Revue Scientifique et Technique, Office International des Epizooties, 15, 1495-525.

69. Stipkovits L., Glavits R., Palfi V., Beres A., Egyed L., Denes B., Somogyi M., Szathmary S. 2012. Pathologic lesions caused by coinfection of Mycoplasma gallisepticum and H3N8 low pathogenic avian influenza virus in chickens. Veterinary Pathology, 49,273-283.

70. Subler K.A., Mickael C.S., Jackwood D.J. 2006. Infectious bursal disease virus-induced immunosuppression exacerbates Campylobacter jejuni colonization and shedding in chickens. Avian Diseases, 50, 179-184.

71. Umar S., Tanweer M., Iqbal M., Shahzad A., Hassan F., Usman M., Sarwar F., Qadir H., Asif S., Nisa Q., Younus M., Ali A., Akbar M., Towakal F., Shah M.A. 2017. Mycoplasma synoviae vaccine modifies virus shedding and immune responses of avian influenza (H9N2) infection in commercial layers. Poultry Science, 96, 3086-3095. doi.org/10.3382/ps/pex149

72. Van Beek P., Feberwee A., Fabri T., Heijmans M.J.H.M. 2002. Longitudinal field study on the presence of Mycoplasma synoviae in meat-turkey flocks with arthritis. In Proceedings, 4th International Symposium on Turkey Diseases, Institute of Poultry Diseases, Free University of Berlin, Berlin, Germany, pp.177-178.

73. Xue J., Xu M.Y., Ma Z.J., Zhao J., Jin N., Zhang G.Z. 2017. Serological investigation of Mycoplasma synoviae infection in China from 2010 to 2015. Poultry Science, 96, 3109-3112. doi: 10.3382/ps/pex134

74. Zhu L., Konsak B.M., Olagoun O.M., Agnew-Crumptona R., Kanci A., Marenda M.S., Browning G.F., Noormohammadi A.H. 2017. Identification of a new genetic marker in Mycoplasma synoviae vaccine strain MS-H and development of a strategy using polymerase chain reaction and high-resolution melting curve analysis for differentiating MS-H from field strains. Veterinary Microbiology, 210, 49-55. doi.org/10.1016/j.vetmic.2017.08.021

Submitted: 16.11.2019. Accepted: 29.12.2019. 